\title{
Major challenges and issues related to wildlife management in Kanha National Park, India
}

\author{
Vivek K. Panwar*, Pradeep Chaudhry \\ Indian Institute of Forest Management, Nehru Nagar, Bhopal \\ *e-mail: vpanwar20@iifm.ac.in, panwarvivek2011@gmail.com
}

Received: 21 February 2019 / Accepted: 28 May 2019

\begin{abstract}
Kanha National Park (KNP) is regarded as one of the oldest and finest wildlife protected areas in India. Though tiger density in Kanha Tiger reserve is highest in comparison to most of other tiger reserves of the country e.g. Tadoba, Melghat, Panna, Pench and Ranthambore tiger reserves, yet Kanha National Park/Tiger reserve is more known for Hard ground Barasingha conservation. Kanha National Park is one of the finest protected area in India but the mentioned problems in the paper can no more be ignored. No doubt park authorities have done very well in management and growth of endangered species but now new challenges have emerged. Improvements can only be done if we know about the list of problems. In the present article, we have discussed the various challenges in wildlife conservation in Kanha National Park like herbivores population, grassland management, poaching, fencing, corridor development activities etc. Significant successes and notable failures on the part of park administration have been discussed.
\end{abstract}

Key words: Grassland, Barasingha, Ungulates, Protection camps, Poaching, Forest Corridor Development, Human wildlife Conflict, Development committees, Endangered Species, Non Timber Forest Products, Protected Area.

\section{Introduction}

When India became independent in 1947, it had less than half a dozen protected areas (Guha, 1997); currently, there are over five hundred protected areas in India, i.e. national parks, wildlife sanctuaries, conservation reserves, community reserves and biosphere reserves. Situated in the Mandla and Balaghat districts of Madhya Pradesh state, the Kanha National Park (KNP) is regarded as one of the oldest and finest wildlife protected areas in India. Kanha was one of the first nine protected areas to be brought under the ambit of the Project Tiger launched by the Government of India in 1973. Kanha is one of the richest biodiversity areas in India with around 22 species of mammals and 300 species of birds (Rathore et al., 2012). The tiger reserve $\left(2074 \mathrm{~km}^{2}\right)$ consists of two conservation entities, namely, the core zone $\left(917.43 \mathrm{~km}^{2}\right)$ and buffer zone $\left(1134 \mathrm{~km}^{2}\right)$. The remaining area of $22.57 \mathrm{~km}^{2}$, not included in the core but technically still a national park, is occupied by villages. The core or the critical habitat is almost completely surrounded by the buffer zone barring part of the eastern boundary running along the Madhya Pradesh-Chhattisgarh interstate border. It is one of the most important tiger reserves of India and is situated in prime Sal forest well known for its rich diversity of endemic mammals and birds (Thakur, 2011). The Park is situated at about $22^{\circ} 45^{\prime} \mathrm{N}$. latitude and $80^{\circ} 45^{\prime} \mathrm{E}$. longitude with elevation varying between $535 \mathrm{~m}$ to $880 \mathrm{~m}$. The landscape and the valleys are open. The average annual rainfall is about $180 \mathrm{~cm}$. The maximum temperature in shade is about $40^{\circ} \mathrm{C}$ in hot season and the minimum temperature is $5^{\circ} \mathrm{C}$ in winter (Chhotani, 1977). There are three distinct seasons, summer, rains, winter in the national park. These seasons greatly vary in temperature, humidity, wind velocity and precipitation, and these factors serve as 
regulators of vegetation and habits of wild animals in the reserve.

As per the bio-geographic classification of India, the national park lies in zone- 6E- Deccan Peninsula- Central Highlands. The Halon and Banjar valleys, forming the eastern and the western parts, two ecological units, of the core zone respectively, are connected by a narrow ridge/ corridor known as chicken's neck. There are six forest ranges in the core zone and six in the buffer. The Phen wildlife sanctuary, a satellite micro-core, of $110.74 \mathrm{~km}^{2}$, is also under the tiger reserve management. Legally, however, the sanctuary has its own status as a protected area.

The objectives of this study are to provide insights about the various issues and challenges faced by Kanha National Park authorities. KNP is one of the finest protected area in India but the mentioned problems in the paper can no more be ignored. No doubt KNP has done very well in management and growth of endangered species but now new challenges have emerged. Improvements can only be done if we know about the list of problems. We have also tried to put some light on good activities and procedures followed by KNP as well, so that various other national parks around the world can learn and know about the management of protected areas.

This protected area is a fine representative of central highlands Sal and mixed woodland and grassy expanses. It is rich in the typical floral attributes of the central Indian highlands. This can be attributed to a number of beneficial factors including the combination of landforms, soil types and moisture regime. The various topographic features of the protected area command special vegetation characteristics. As per Champion and Seth (1968) forest classification, KNP supports three types of forests i.e. moist peninsular high level Sal and Moist peninsular low level Sal forests (Fig. 1), Southern tropical moist deciduous mixed forests and Southern tropical dry deciduous mixed forests. Most common tree associate of Sal is Saja (Terminalia tomentosa), while other species of core (upper areas) include Achar (Buchanania lanzan), Aonla (Phyllanthus emblica), Tendu (Diospyros melanoxylon), Terminalia chebula and Terminalia bellerica. Depressions, along rivers, have Mango, Jamun and Arjun. Dendrocalamus strictus is the main bamboo species. Mahul (Bauhinia vahlii) is the most common tree climber crowning tree species and span the space between trees. Open areas and affected by fire have more proportion of hardy species like Palas (Butea monosperma), Tendu (D. melanoxylon) and Lendia (Lagerstroemia parviflora).

\section{Importance of being Kanha}

Though tiger density (over 10 per $100 \mathrm{~km}^{2}$ ) in Kanha Tiger reserve is highest in comparison to most of other tiger reserves of the country e.g. Tadoba, Melghat, Panna, Pench and Ranthambore tiger reserves (Karanth et al., 2004), yet Kanha National Park/Tiger reserve is more known for Hard ground Barasingha conservation. Therefore, a special at-

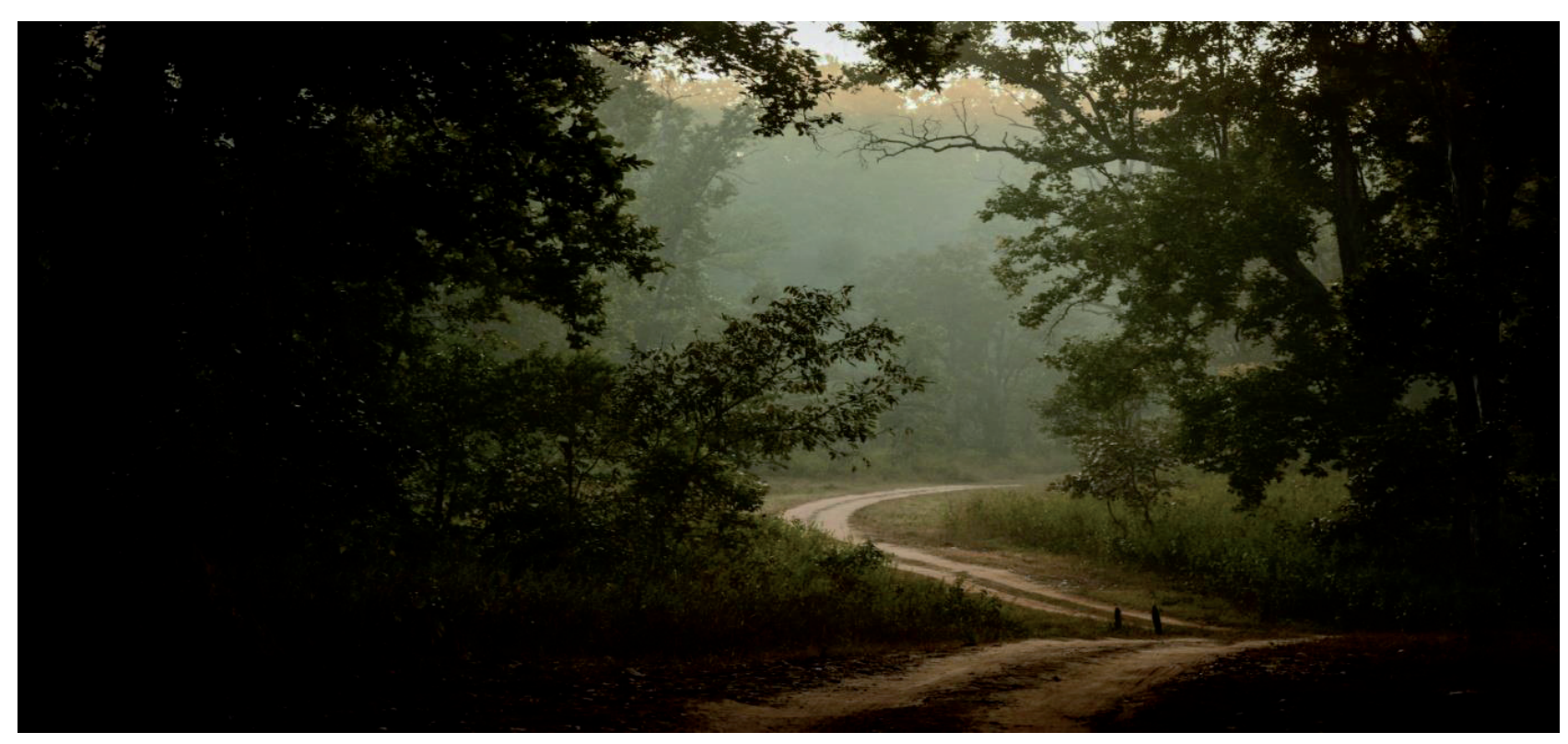

Figure 1. Meandering Kanha safari track with moist Sal forest in background on a misty morning (Photo by Vivek Kr. Panwar) 
tention is paid to Hard ground Barasingha or Central Indian Swamp deer (Cervus duvauceli branderi) management in the present article while discussing various wildlife management issues in Kanha. During 1970 only 66 individuals were left in KNP (Singh et al., 2015). Special conservation measures were under taken by the park management to reverse the declining trend, and due to these efforts there are now around 475 animals in the park (Prakash et al., 2012). Moreover, Central Indian Swamp deer is among four most highly endangered ungulate species of India, which need special attention for conservation (Daniel, 1991).

\section{Issues and Challenges}

Grasslands - Kanha has grasslands in $8 \%$ of its total area. This is very important keeping in view the management of Barasingha. This species of deer mainly prefers eating grasses and aquatic plants (Schaller, 1967; Martin, 1977; Schaaf, 1978; Singh, 1984; Moe, 1994; Qureshi et al., 1995; Pokharel, 1996 and Tewari \& Rawat, 2013), remains close to water bodies most of the time, where other herbivores like spotted deer, barking deer, Sambar can eat anything like tree leaves, twigs etc. Actually well established standards say to have $15 \%$ grasslands (personal communication with park authorities) but Kanha is lacking on this front. It is a big challenge to keep so many ungulates (mainly deers) in a national park (KNP here) when grasslands are limited and much below the standard (Table 1). Barasingha require specific conditions in grassland. It requires tall grasses. Maintenance of tall grass cover is required as fawning cover for this species. This is important as fawns (newly born) of this species need 24 to 48 hours to stand and walk in jungle whereas newly born in case of other deer like spotted deer and sambar start walking within one hour of the birth. Somehow uptill now Kanha administration is successful in preservation and growth of Barasingha but keeping future needs in mind, this grassland cover is going to be inadequate and so better and out of the box thinking in grassland management is required right now.

Deer population - There are lot of spotted deer, sambar and barking deer in the national park (Table 1 and Fig. 2). This is a very huge number. Keeping grasslands and eating resources in mind, grasslands are inadequate. These numbers can become unsustainable in future in lack of proper management (Fig. 3). Such large number of spotted deer and sambar can create problem in management of Barasingha and other species like Indian mouse deer (Moschiola meminna), and black buck (Antilope cervicapra). Barasingha only eats grasses and that grass should be of certain height to provide fawning cover. So these spotted deer can create food issues for Barasingha as they will not allow grass to grow to reach up to a certain height. National parks and nearby sanctuaries like Manas in Assam face shortage of spotted deer and sambar causing narrowing down of the prey base for tiger, hence there is an immediate requirement to shift these deer to areas like Manas. In other words, herbivore population management requires a large-scale approach, management of herbivore impacts on vegetation may require a much more flexible and site-specific approach (Gordan et al., 2004).

Table 1. Ungulate population in Kanha National Park (2017)

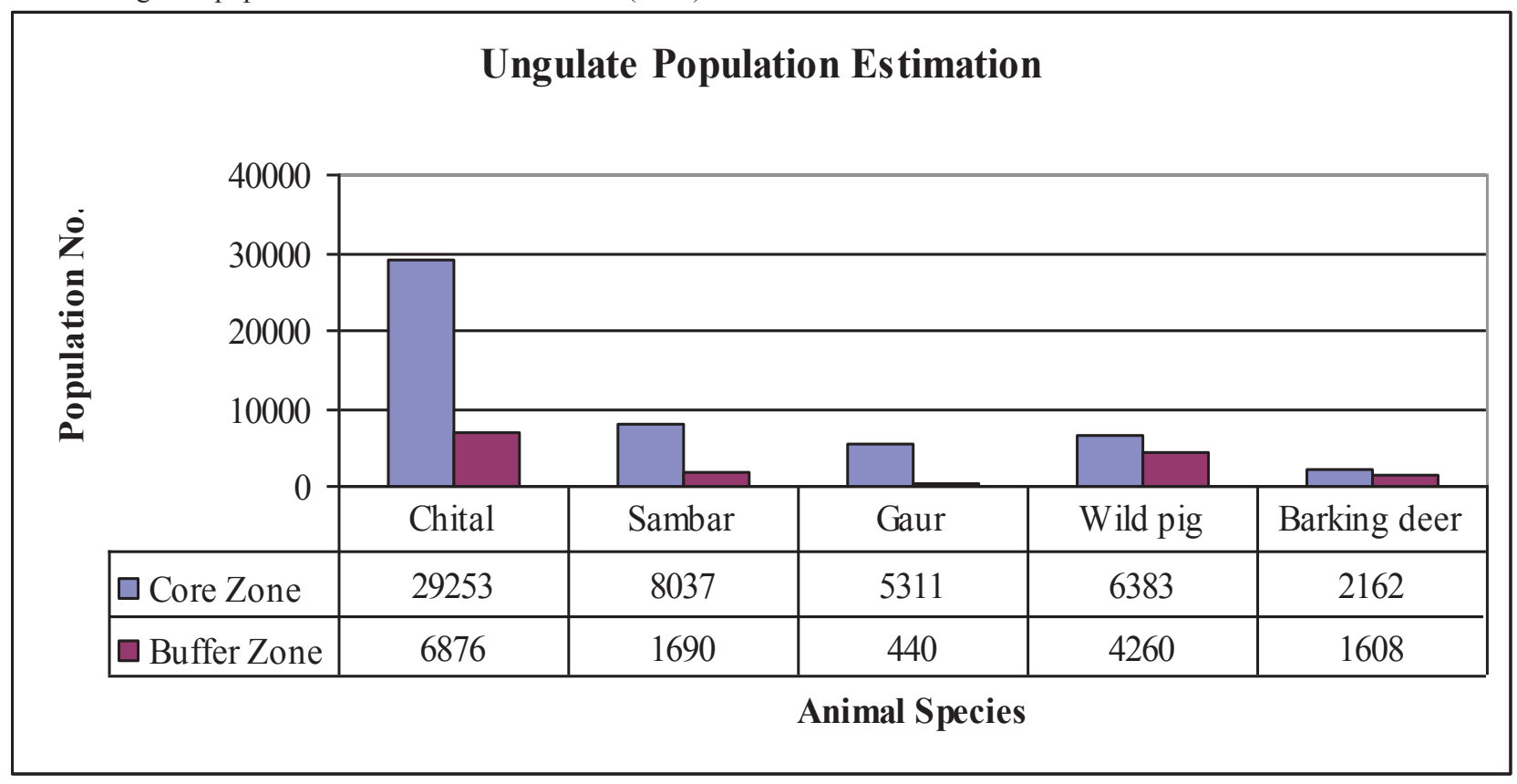




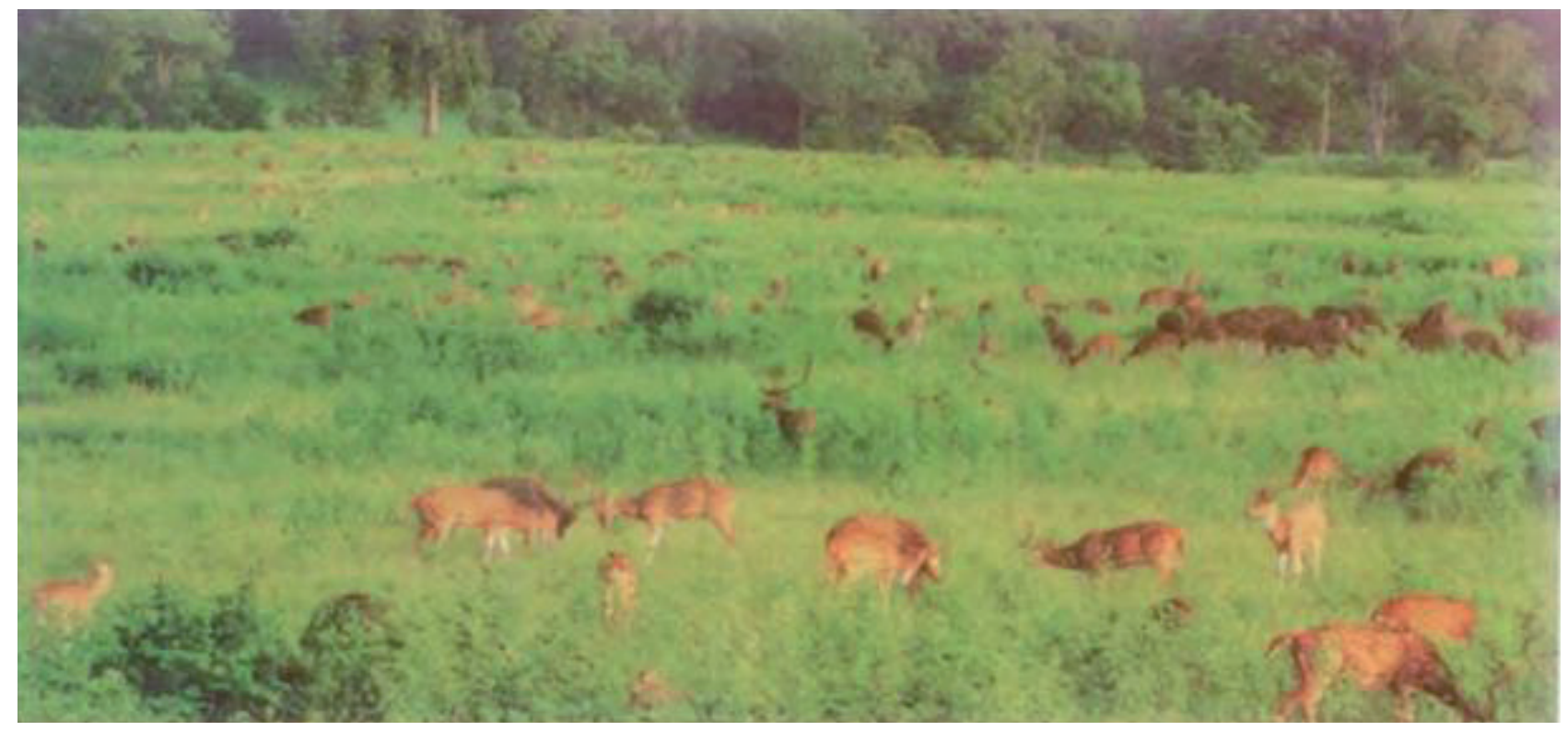

Figure 2. A large population of spotted deer and sambar grazingin the park (Photo by Vivek Kr. Panwar)

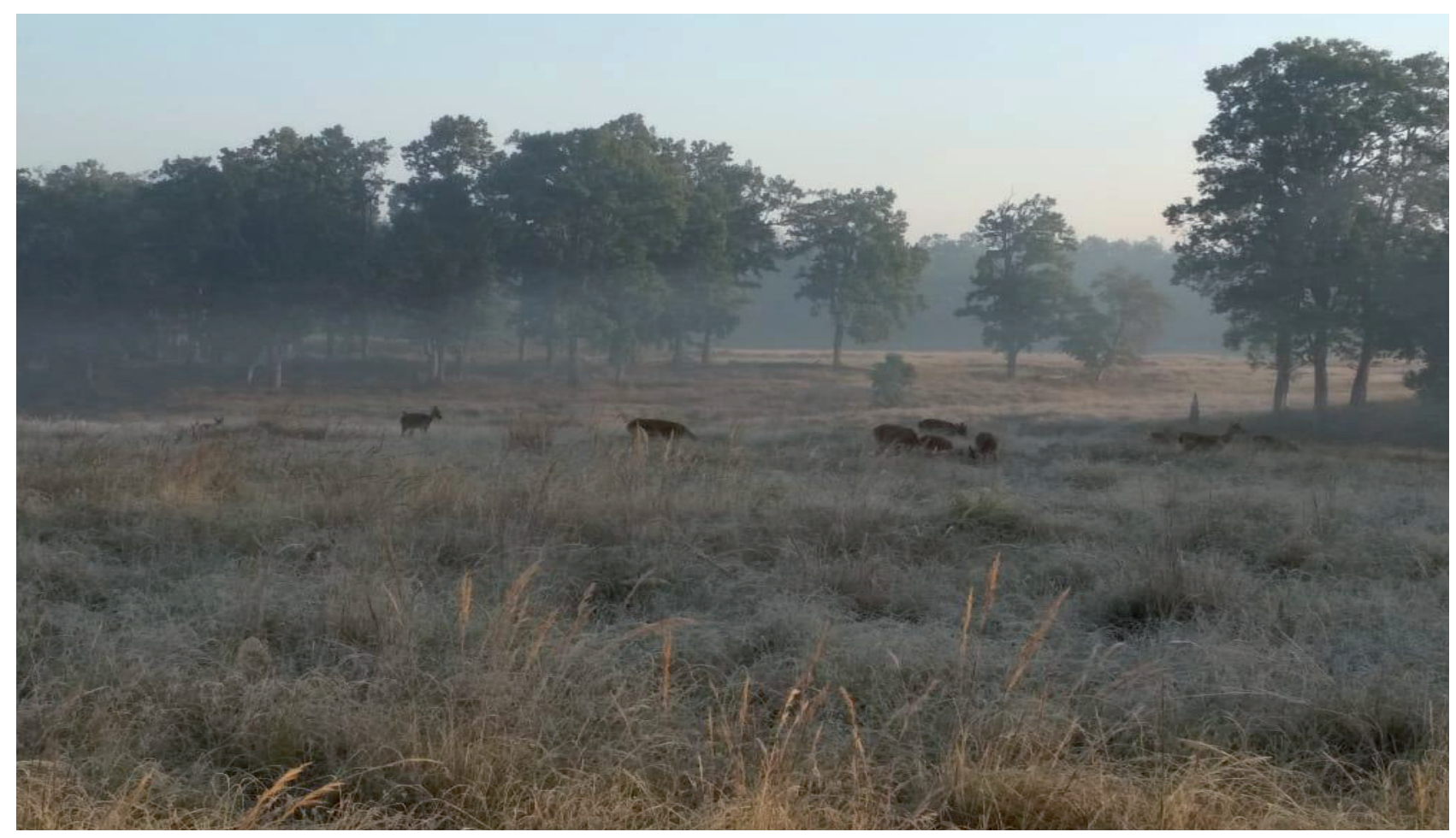

Figure 3. Grass height is a deciding factor for Barasingha at KNP (Photo by Vivek Kr. Panwar) 
Protection camps - Kanha is known for its good management activities (Fig. 4). But there are some issues regarding management and use of protection team camps in the national park. Many camps do not have required guards in night. Absence of guards in night is not a healthy sign for that particular area particularly in sensitive buffer areas with respect to past poaching cases. Although various mobile applications have been developed by Kanha administration for guards but still adoption of technology in management of park and use by forest guards is somewhat lacking.

Poaching - There are stray incidents of poaching in the park. Although numbers are very less (27 cases in last two years i.e. 2017 and 2018 as per personal communication with park authorities) but still loopholes are there. As mentioned above, forest guards are not available at certain places. Kanha officers have developed a robust system to catch the culprits but that hardly matters to an animal that is already dead due to the negligence of forest department at first place. Kanha has some sensitive points from the view point of poaching. Kanha administration needs to take care of those specific points.

Fencing of the park - Kanha does not have complete fencing. This is one of the reasons for the stray incidents of poaching. Fencing acts as primary resistance for the people from outside as well as for the animals. Kanha administration is thinking about this particular issue but it will be better if they do it in mission mode and complete the work as soon as possible.

Forest Corridor development and management Development of corridors is very general thing nowadays. There are corridors around Kanha which connect it with other forest areas such as Pench tiger reserve, Nagzira tiger reserve, Nawegaon tiger reserve, Bhoramdeo wildlife sanctuary and Achanakmar tiger reserve. But these corridors have been developed keeping in mind the movement of tiger. Now Kanha administration also paying attention about the movement of Barasingha. So some adjustments or development of these corridors is required by removing villages from these areas. This task is not going to be simple in a democratic and heavily populated country like India but still beginning and rethinking has to be done.

Management of other species- Kanha is known for management activities for tiger and Barasingha but there are other vulnerable species as well such as black buck and mouse deer. Park is taking no initiative for such species. Kanha National Park has resources and expertise in management of vulnerable species. So efforts should be

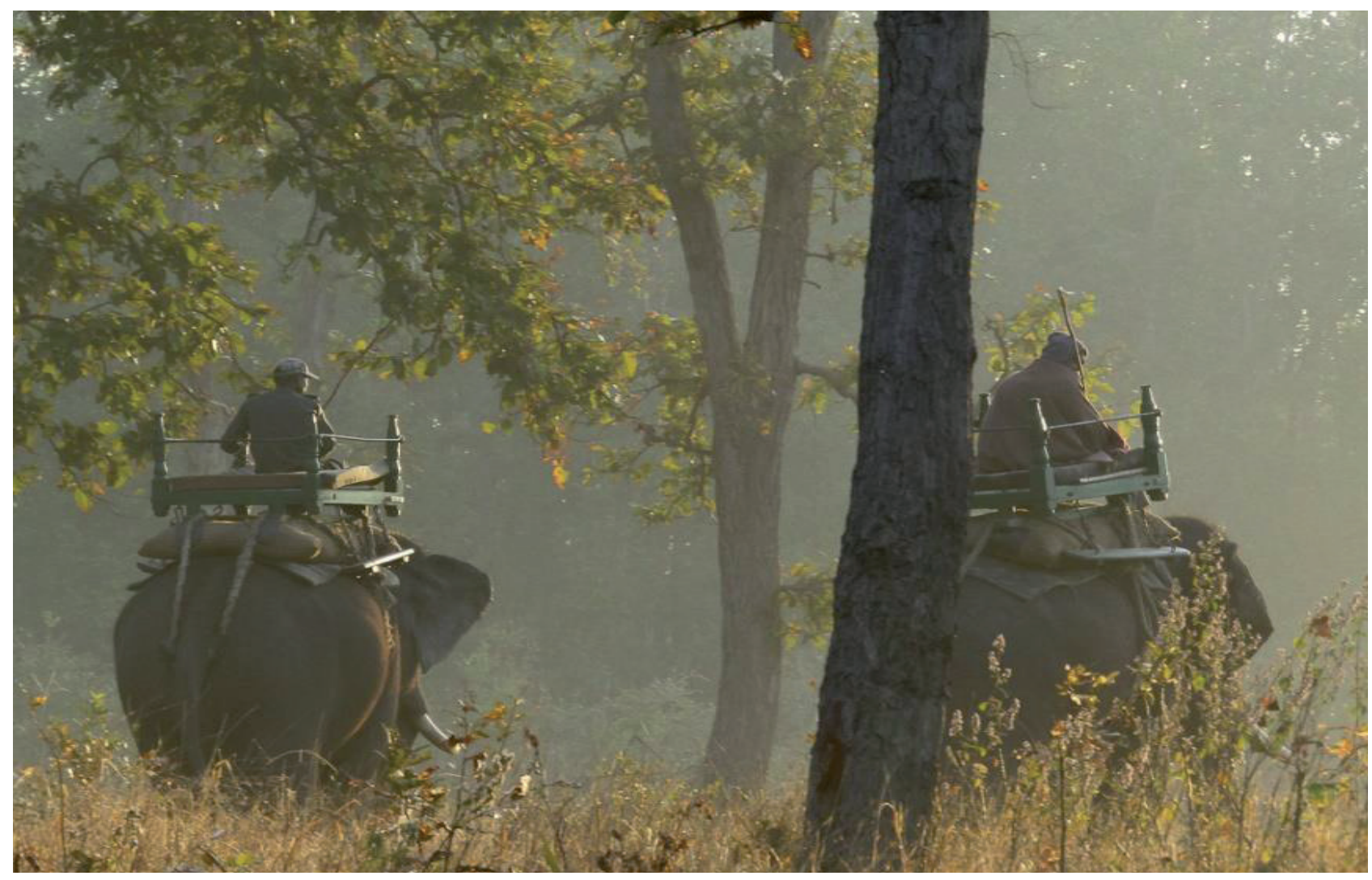

Figure 4. Elephant patrolling in Kanha National Park (Photo by Vivek Kr. Panwar) 
made by Kanha administration for preservation of some other species as well.

Human wildlife conflict in buffer areas- There are some incidents of such conflicts in buffer areas. According to local villagers living in nearby villages of KNP, leopard was the most common agent for livestock damage whereas sloth bear for human casualty (Ahmed et al., 2012). According to authors, such conflicts create negative impact on local community but still they have positive attitude towards carnivore conservation. Karanth et al. (2013) reported that carnivores were not viewed with more hostility than crop raiding wild animals like wild boars and deer by the local households near KNP who showed more inclination to kill herbivores destroying crops but not carnivores preying on livestock. Kanha administration should solve above mentioned issues to reduce such conflicts in future. Kanha National Park provides compensation for any loss due to such conflicts but KNP should make efforts to expand awareness regarding the use of resources in buffer areas. "Chicken's neck" is specifically critical from the point of view of such conflicts. So extra care in those areas should be taken by people as well as forest department.

\section{Discussion and Conclusion}

Kanha national park administration has successfully translocated many species from this park to others in past two years e.g. reintroduction of 50 Gaur into the Bandhavgarh Tiger Reserve from Kanha Tiger Reserve, reintroduction of 50 blackbucks in Kanha Tiger Reserve from other regions, successful translocation of 7 Barasingha from Kanha to Van Vihar National Park, Bhopal, successful translocation of 22 Barasingha from Kanha tiger reserve to Satpura Tiger Reserve, successful translocation of 1 tiger from Kanha to Satpura Tiger Reserve.

Kanha park administration has been conducting awareness programmes/camps to nearby school children e.g. 10 such camps were arranged for school students (around 240 numbers) of buffer villages during the year 2016-17 (Fig. 5), which includes jungle excursions, trekking and stay. Important information related to forest, wildlife and nature conservation is provided to the students in such camps.

There are 140 Eco Development Committees (EDCs) in buffer zone of the park formed under joint forest man-

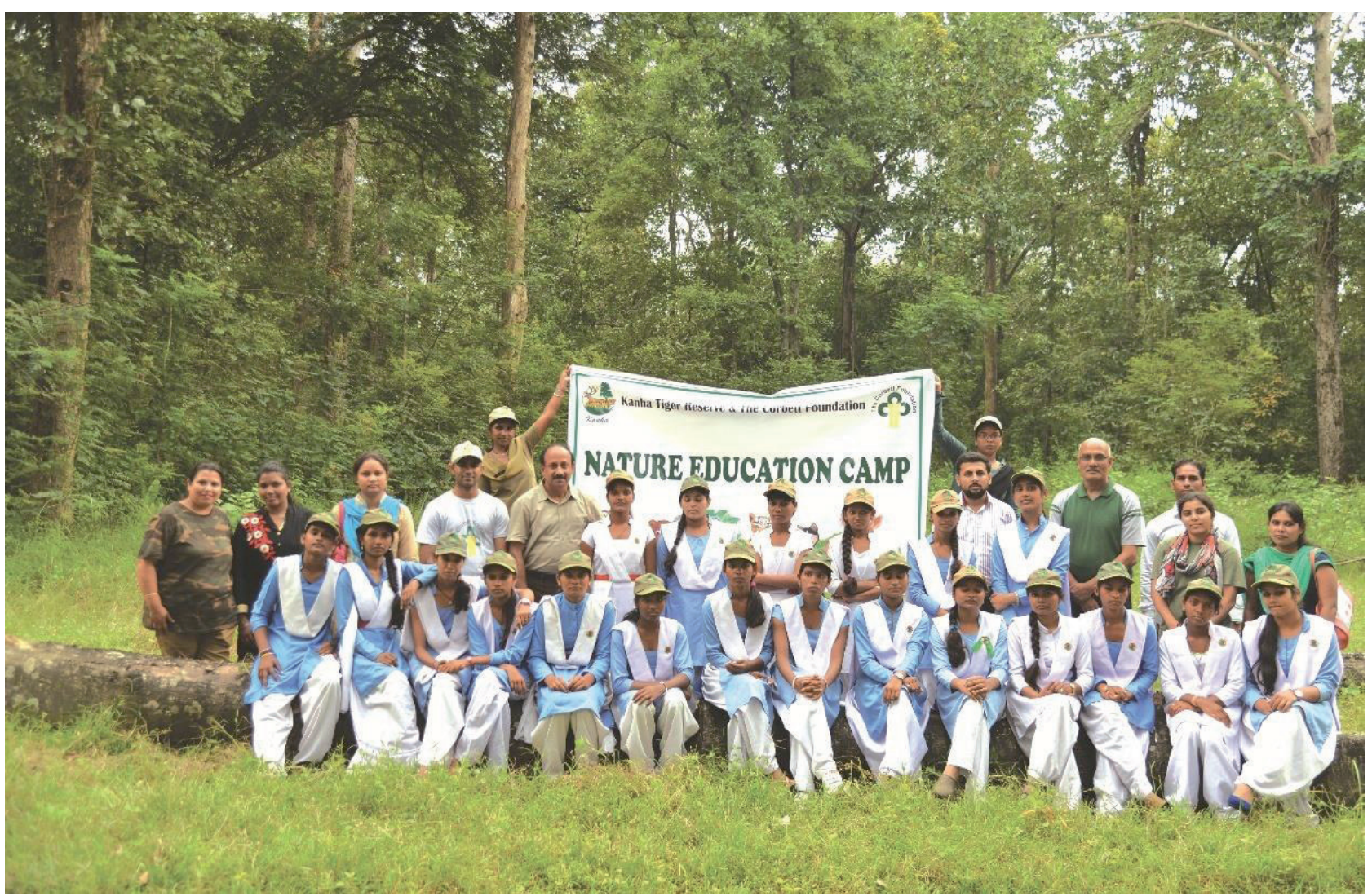

Figure 5. Nature education camp organized in 2016-17 at KNP for school children (Photo by Vivek Kr. Panwar) 
agement resolution of Government of Madhya Pradesh. Annual meetings of General bodies are held under the chairmanship of Field Director of the park. Proposals like approach roads, bio gas plants, wells, school building, community centers, hand pumps installation are discussed and approved in the villages out of total revenue received through gate fee, which is about Rs. 75 million per year now. Medical facilities through health camps are provided to villagers. Provision of soft loan for starting small businesses is also there. Kanha Vikas Nidhi (Development fund) is there out of overall revenue earned. Kanha park management always encouraged local tribes to maintain cultural identity. Money is also provided to EDCs for purchasing musical instruments, dresses for folk dances. Nearby hoteliers arrange special ethnic dances for the visitors.

Managing this tiger reserve has been a great learning process for the park administration. On one side, reserve management can boast of many successes, it had to taste some failures also. Notable successes include effective conservation of the highly endangered population of tiger (48 in 1976 to 80 plus now), building up of prey base for sustaining a viable population of tiger and other copredators (i.e. wild ungulates), successful conservation of Barasingha in the park, overall water availability in lean season was improved, effective protection by different means including intelligence gathering was improved. Successful relocation of 28 villages from core area of the park and vacated village sites were metamorphosed into beautiful heterogeneous grasslands, effective fire protection involving fire squads, fire towers, fire maps and fire area kept below $2 \%$ of total area, development of effective intelligence network for pre-empting and countering wildlife offences, no epidemic/mass mortality of animals recoded since 1976, regular cattle immunization in nearby villages, establishment of Kanha Vikas Nidhi (Development fund) for socioeconomic upliftment of nearby village people, and promotion of awareness among stakeholders for conservation.

Notable failures include that seven forest villages which were relocated to near periphery of park, still exert pressure on the park for firewood and non timber forest products (NTFP) collection. Actually these should have been shifted 7-8 km away but not done. People in relocated villages are not satisfied with facilities provided e.g. agricultural land is rocky and stony (Jha \& Chaudhry, 2018). Smokeless Chullahs (stoves) promoted by management have not been accepted by people, however Gobar (cowdung) gas plants are popular (pers. comm. with the Baiga tribe, a local community inthe locality).

Although there is widespread agreement on the importance of maintaining natural areas and their associated flora and fauna, the total amount of area given protected status is frequently insufficient in developing countries, and the level of funding provided for management is almost always inadequate (Jha \& Chaudhry, 2018). Establishing and maintaining Protected Areas (PA) require both political and financial commitment in the long term (Bruner et al., 2004). A major reason for this is that the benefits to society from PAs are often grossly underestimated, and the immediate costs of protection appear large in comparison. Some researchers have tried to estimate such intangible benefits to society from PAs. For example, economic valuation of tiger reserves, invariably National Parks in India, may provide the economic rationale for such resources and support biodiversity conservation and human wellbeing. Some however argue the contrary, that there are social costs incurred by the dislocated people due to formation of PAs (Menon \& Rai, 2017). One study examined six tiger reserves of India in different landscapes and found that the flow benefits from these reserves ranged from 50,000 INR/ha/year (769 US\$/ha/year) to $190,000 \mathrm{INR} /$ ha/year (2,923 US\$ /ha/year). The lower value was of a reserve in the tropical dry deciduous forest region, where Ranthambore Tiger Reserve, Rajasthan is located while the higher value was of a reserve in the tropical moist evergreen forest region where Periyar Tiger Reserve, Kerala, is located (Verma et al., 2017). Therefore, nearly 5\% of India's geographical area covered by PAs is responsible for providing ecosystem services or benefits flow worth millions annually. This shows the huge significance of these areas for the ecological and social security of society and other living systems of the country.

Kanha National Park earns total revenue of around Rs. 75 million annually; it has best officers of forest department. These challenges and issues could be solved if administration pays attention and pursues matter of importance with government. For each issue some steps can be taken. Solution of one issue will help in solution of another issue. Like extra number of spotted deer could be translocated to other places like Manas National Park in Assam to reduce biotic pressure in Kanha. Similarly technology could be used in management of park as well to check positions of guards in night. Ex-servicemen can be recruited for better management of sensitive points because poachers enter in the park through those places. For management of other species like black buck, the infrastructure created for Barasingha could be used. There is no simple rule for conservation objectives with local species. What has worked in one Protected Area (PA) may not have worked in another. Understanding the unique characteristics of each PA and the animal species who live in is vital for the success of each PA's conservation program.

\section{References}

Ahmed R.A., Prusty K., Jena J., Dave C., Das S.K.R., Sahu H.K. \& Rout S.D., 2012, Prevailing human carnivore 
conflict in Kanha-Achanakmar corridor, Central India. World Journal of Zoology 7(2): 158-164.

Bruner A.G., Gullison R.E. \& Balmford A., 2004, Financial costs and shortfalls of managing and expanding protected area systems in developing countries. BioScience 54(12): 1119-1126.

Champion H.G. \& Seth S.K., 1968, A Revised Survey of Forest Types of India. Manager Publication, New Delhi, India.

Chhotani O.B., 1977, Termites of Kanha National Park, Madhya Pradesh, India. Records of the Zoological Survey of India 72: 367-378.

Daniel J.C., 1991, Ungulate conservation in India - problems and prospects. Applied animal behavior science 29(1-4): 349-359.

Gordan I.J., Hester A.J. \& Festa-Bianchet M., 2004, The management of wild large herbivores to meet economic, conservation and environmental objectives. Journal of Applied Ecology 41: 1021-1031. (https://doi.org/10. 1111/j.0021-8901.2004.00985).

Guha R., 1997, The Authoritarian Biologist and the arrogance of anti-humanism conservation: Wildlife conservation in the third world. The Ecologist 27(1): 14-20.

Jha K.K. \& Chaudhry P., 2018, Unravelling the Complexity of Protected Area Management in Two Developing Countries: Issues of Human Displacement and Wildlife Conflict, [in:] Martin O’Neal Campbell (ed.), Geomatics and Consrvation Biology. Nova Science Publishers, New York, USA.

Karanth K.U., Nicholas J.D., Kumar N.S., Link W.A. \& Hines J.E., 2004, Tigers and their prey: Predicting carnivore densities from prey abundance. PNAS (Proceedings of the National Academy of Sciences of the U S of America) 101(14): 4854-4858.

Karanth K.K., Naughton-Treves L., Defries R. GopalaswamyA.M., 2013, Living with wildlife and mitigating conflicts around three Indian protected areas. Environmental Managemen 52(6):1320-1332. (doi: 10.1007/s00267-013-0162-1).

Martin C., 1977, Status and ecology of the barasingha (Cervus duvauceli branderi) in Kanha National Park (India). Journal of the Bombay Natural History Society 74: 60-132.

Menon A. \& Rai N.D., 2017, Putting a price on Tiger reserves. Creating conservation value or green grabbing? Economic and Political Weekly 52(52): 23-26.

Moe S.R., 1994, The importance of aquatic vegetation for the management of the Barasingha (Cervus duvaucelii) in Nepal. Biological Conservation 70(1): 33-37.
Pokharel C.P., 1996, Food habit and habitat utilization of swamp deer (Cervus duvauceli duvauceli) in Royal Bardia National Park, Nepal. M.S. thesis, Tribhuvan University, Kirtipur, Nepal.

Prakash R., Nayak K., Pandey R.K., Shukla R., Homkar U., Saini S.K., Jain R., Haldkar V., Nema S., Deshmukh S., Thakre R. \& Koshta A., 2012, Habitat Viability Analysis for the Proposed Reintroduction Site for the Hard-ground Barasingha (Cervus duvauceli branderi) in the Bori Wildlife Sanctuary, Satpura Tiger Reserve (Madhya Pradesh). Report by State Forest Research Institute, Jabalpur (M.P.), India.

Qureshi Q., Sawarkar V.B. \& Mathur P.K., 1995, Ecology and management of swamp deer (Cervus duvauceli) in Dudhwa Tiger Reserve, U.P (India). Project Report, Wildlife Institute of India, Dehradun, India.

Rathore C.S., Dubey Y., Shrivastava A., Pathak P. \& Patil V., 2012,Opportunities of Habitat Connectivity for Tiger (Pantheratigris) between Kanha and Pench National Parks in Madhya Pradesh, India. PLoS ONE 7(7): e39996. (https://doi.org/10.1371/journal. pone.0039996).

Schaaf C.D., 1978, Population size and structure and habitat relation of the swamp deer (Cervus duvauceli duvauceli) in Suklaphanta Wildlife Reserve, Nepal. Ph.D. thesis, Michigan State University, East Lansing, USA.

Schaller G.B., 1967, The Deer and the Tiger. Chicago University Press, Chicago, Ill, USA.

Singh C.P., Chauhan J.S., Parihar R.P. \& Shukla R., 2015, Using environmental niche modelling to find suitable habitats for the Hardground Barasingha in M P, India. Journal of Threatened Taxa 7(11): 7761-7769.

Singh V.P., 1984, Bio-ecological studies on Cervus duvaucelii duvaucelii, swamp deer (barasingha) in Dudhwa forest near Indo-Nepal border. Ph.D. thesis, D.A.V. College, Kanpur University, India.

Tewari R. \& Rawat G.S., 2013, Studies on the food and feeding habits of Swamp deer (Rucervus duvaucelii duvaucelii) in Jhilmil Jheel conservation reserve, Haridwar, Uttrakhand, India. ISRN Zoology, Hindawi Publishing Corporation. (http://dx.doi.org/10.1155/2013/278213).

Thakur S., 2011, A note on snakes of Kanha National Park and surrounding areas. REPTILE RAP \# 11: 02-05.

Verma M., Negandhi D., Khanna C., Edgaonkar A., David A., Kadekodi G., Costanza R., Gopal R., Bonal B.S., Yadav S.P. \& Kumar, S., 2017, Making the hidden visible: Economic valuation of tiger reserves in India. Ecosystem Services 26: 236-244. 